\title{
Corporate Social Responsibility Reporting, Pyramidal Structure And Political Interference: Evidence From China
}

\author{
Jianling Wang, Xi'an Jiaotong University, China
}

Mi Zhou, Virginia Tech, USA

Lijun Lei, Virginia Tech, USA

Weiguo Fan, Virginia Tech, USA

\begin{abstract}
This paper attempts to investigate the relation between pyramidal structure and corporate social responsibility $(C S R)$ reporting quality and the effect of political interference on the relation. Based on 1388 Chinese A-share listed firms during 2010-2012, this paper demonstrates that the separation between control and ownership rights is significantly and positively related to the CSR reporting quality in the state-owned firms (SOFs), while negatively related to the CSR reporting quality in the non-state-owned firms (NSOFs). Results also indicate that the pyramidal layer between the bottom firms and their top ultimate owners is negatively related to CSR reporting quality, particularly significant for the NSOFs. Our research enriches the corporate governance literature by giving insights into the mechanism of pyramidal structure in corporate reporting, and extends the understanding of political interference in the CSR field. This study has public policy implications for China as well as a number of other countries in the Asia-Pacific region.
\end{abstract}

Keywords: Corporate Social Responsibility (CSR) Reporting; Reporting Quality; Pyramidal Structure; Political Interference

\section{INTRODUCTION}

orporate Social Responsibility (CSR) reporting has been a mainstream global business practice over the past decades. A survey of CSR reports by KPMG International indicates that nearly 93\% of the largest 250 firms in the world issued standalone CSR reports in 2013, and almost three quarters of the 100 largest companies surveyed in 41 countries publishing the CSR reports. This survey also indicated that Asia Pacific region has demonstrated a dramatic increase in CSR reporting rates over the past few years, as a result of the introduction of government regulation or guidelines from stock exchanges and other organizations. With the increase in the number of CSR reports, however, a concern for the low quality of CSR reporting has attracted a widespread attention (KPMG International, 2013; China WTO Tribune, 2009).

Prior literature extensively explores the cultural and institutional factors that potentially influence the firms' attitudes and actions in disclosing corporate social information (Buhr and Freedman, 2001; Haniffa and Cooke, 2005). By comparing the environmental disclosure by Canadian and US firms, Buhr and Freedman (2001) find that the collectivistic nature of Canadian society is more likely to induce the voluntary environmental reports, while the litigious nature of US leads to produce more of the mandated reports. Haniffa and Cooke (2005) emphasize the impact of corporate governance on the corporate social disclosure of Malaysian companies, especially the board characteristics. They demonstrate a significant relationship between corporate social disclosure and different board structures such as boards dominated by Malay directors, boards dominated by executive directors, and boards chaired with multiple directorships. In addition, Haniffa and Cooke (2005) also provide evidence on the effect of the foreign share ownership on the CSR disclosure. Coincidently, Aguilear et al. (2006) investigate the role of another salient type of owner, institutional investors, in emphasizing the firm-level CSR actions. They find that the difference between the UK and US firms in the CSR field results from the differences in the composition of 
institutional investors. These findings have at least two implications: 1), the corporate governance arrangement is an important aspect that influences the corporate disclosure; 2), the corporate owner could affect the attitudes and actions that firms take in CSR. Therefore, by taking the perspective of corporate governance, this paper attempts to investigate the potential reasons why the quality of CSR reporting in Asia Pacific region is low.

We take the emerging Chinese market as our empirical research context for the following three reasons. Firstly, China is the largest developing economic body in Asia. Previous research mostly focuses on CSR report in the developed countries such as US, UK and other European countries (Holder-Webb et al. 2009; Mahoney et al. 2013), little attention has been given to the CSR in Asian countries. Our study would be helpful to understand the current status of CSR reporting in this region. Secondly, there are similar driving forces for CSR reporting between China and other Asian countries. CSR reporting is significantly driven by the government in most Asian countries (KPMG, 2013). For instance, the Chinese Stock Regulatory Commission (CSRC) made the CSR report a mandatory requirement for some listed firms in 2008. Triggered by such mandatory disclosure initiation, the number of Chinese listed firms issuing CSR reports jumped from only 21 in 2006 to 371 in 2009. After Malaysian Stock Exchange requires that listed firms report on CSR activities, the percentage of firms that report CSR increases from almost zero in 2011 to $98 \%$ in 2013. In Singapore, the introduction of the Singapore Stock Exchange Sustainability Reporting Guide for listed firms has led to a 37 percentage point increase in CSR reporting rate. Lastly, there is a large similarity between China and other Asian countries with regard to the corporate governance and institutional environment. For example, the corporate ownership is highly concentrated, and a majority of firms are controlled by the state in a number of Asian countries (Fan and Wong, 2002), representing a highly political interference on corporate governance. Claessens et al. (2000) also indicates that there are $23.6 \%$ firms in Singapore, $18.2 \%$ in Malaysia and $63.15 \%$ in China having the state as ultimate owner respectively, much higher than the percentage in the other countries (Faccio and Lang, 2002; Li and Zhang, 2010). More importantly, Asian firms usually build complicated pyramidal structure to exert their control (Fan and Wong, 2002; Fan et al., 2012). And hence, by using 1388 Chinese listed A-share firms that issued their standalone CSR reports during the period of 2010-2012, this paper investigates the potential effect of widespread pyramidal structure on CSR reporting disclosure, and the effect of government political interference on the relationship. Our results would have policy implications for China and other Asian countries with similar governance and political environment.

This study contributes to the literature in two ways. First, this study directly examines the effect of pyramidal structure on CSR reporting quality in an attempt to deeply understand the relation between corporate governance and non-financial information quality. CSR reporting has been regarded as the most important source of nonfinancial information for investors (Eurosif and ACCA, 2013). Our results are helpful to understand the mechanism how corporate ownership structure influences CSR information quality. Second, this paper provides evidence on the different characteristics of pyramidal structure between state-owned firms (SOFs) and non-state-owned firms (NSOFs) and examines the effect of political interference on corporate disclosure quality. The earlier literature mostly pays attention to the pyramidal structure across East Asia, particularly the family controlled firms (Claessens et al. 2000, Fan and Wong 2002). However, evidence indicates that quite a lot of Asian firms are controlled directly or indirectly by the state, which has a different purpose of pyramiding from the NSOFs (Fan et al., 2005). Li and Zhang (2010) demonstrate an opposite effect of ownership dispersion on CSR level between SOFs and NSOFs. This paper provides further evidence on how politically interfered pyramid structure affect corporate information quality.

The paper is organized as follows. In the next section, we review relevant literature and develop the hypotheses. Section 3 outlines the study design and research methodology. Section 4 presents empirical results and their interpretations. Section 5 concludes the paper with a description of its implications.

\section{LITERATURE REVIEW AND HYPOTHESIS DEVELOPMENT}

\subsection{Literature Review}

Corporate governance, the system by which companies are directed and controlled (Cadbury Code, 1992), has been used to explain differences in finance and the role of the market for corporate control. Due to the divergence of political, social and cultural environment, however, the divergent corporate governance of different countries can further influence and determine the modes of CSR practices. Aguilera et al. (2006) compared the corporate 
governance and CSR practices in the UK and US, and found that some salient differences exist between the corporate governance in the US and UK. For example, the composition of institutional investors in these two nations was different. Insurance companies and pension funds predominated in the UK, while investment companies and mutual funds were the largest institutional investors in the US. Because different investors have significantly different performance strategies, they could offer distinct pressures on the firm and its stakeholders and hence influence the attitude to the CSR practices. Compared with the US investors, the institutional investors in the UK with a longer-term perspective are more likely to see a company's social and environmental behavior as material to investment decisions (Aguilera et al., 2006). Therefore, the corporate governance, in particular the ownership structure, is a key to influence and determine the firm's attitude to the CSR practices.

The majority of existing literature of ownership structure focuses on immediate ownership - common stocks directly owned by individuals or organizations. However, the body of corporate governance literature provides evidence that East Asian firms are generally associated with complicated indirect ownership- pyramidal ownership structure (Claessens et al., 2000; Fan and Wong, 2002), which is an important mechanism used by the ultimate owners to separate their cash flow ownership from their control rights, with a purpose of obtaining more interests deriving from more control rights (La Porta et al. 1999). Some research investigates the potential effect of pyramidal structure on firm performance (Fan et al., 2005; 2007), and financial information quality (Fan and Wong, 2002; Zhu, 2006). However, little attention has been given on the relations between pyramidal structure and CSR reporting. Being one of the most important parts of corporate information, CSR report can help stakeholders know what the firms have done, signaling their good performance to the stakeholders and reducing the degree of information asymmetry between stakeholders and corporate management (Hendarto and Purwanto, 2012). And hence, we investigate the potential influence of pyramidal structure on CSR reporting quality. Specifically, we try to study two questions. The first is the relation between pyramidal layers and CSR information quality. The second is the relation between the control-ownership rights separation and CSR information quality.

In addition, as mentioned earlier, a number of East Asian firms are controlled by the state ultimately. Due to the different property constraints between the state and the individual owners, however, their purpose of pyramiding is divergent (Fan et al., 2005). The state uses pyramiding to credibly decentralize their firm control rights to firm management without selling off their ownership, while the individual owners use pyramiding to create internal capital markets that help relieving their external financing constraints. Li and Zhang (2010) also provide empirical evidence that SOFs and NSOFs have a wholly different attitude to the CSR practice. In the meanwhile, the motivation to publish information is also different between the NSOFs and SOFs. In the NSOFs, the motivation to publish information is weak except for mandatory regulation (Chau and Gray, 2002). Nevertheless, SOFs are willing to provide related information through CSR reporting to signal their good deeds (Ghazali, 2007; Wang et al., 2012), because these firms may be set up not only to achieve profit maximization, but also to fulfill a range of social objectives. Thus, we further divide the two arguments pertaining to the relations between the pyramidal ownership structures and CSR reporting quality, and investigate them in the state-owned firms and non-state-owned firms respectively to observe the influence of political interference on the relations.

\subsection{Hypothesis Development}

Pyramidal structure refers to "the sort of corporate ownership structure through which the ultimate owner establishes control over several layers of firms via a very small capital investment" (Zhu, 2009). In a pyramid-like corporate structure, the number of intermediate pyramidal layers between the bottom firm and its top ultimate owner represents the extent of a pyramidal structure. In the simplest circumstance, the intermediate pyramidal layer between the bottom firm and its top ultimate owner is only one - both the equity ownership and control rights are directly held by the controlling shareholder, who faces the same agency problem and have the same need to get information from the bottom firms as the other non-controlling shareholders. When the number of pyramidal layers increases between the bottom firm and its top ultimate owner, however, the firm will be controlled by the ultimate owner rather than the controlling shareholder, which reduces the controlling shareholder's motivation to regulate the bottom firms. The more layers in a pyramidal structure, the more serious the agency problems are. For the non-stateowned firms, the main purpose of pyramiding is to build an internal financing market (Fan et al., 2005) to fill in the financing gap. Because of the absence of strong desire to attract social attention to get their needed fund, the NSOFs would not have motive to disclose CSR information voluntarily. Moreover, the ultimate owner of NSOFs may find it 
advantageous to restrain the extent of information disclosure in order to achieve its self-serving interests, which ultimately leads to a lower transparent information disclosure. And thus, we expect that the pyramidal layer is negatively related to the CSR reporting quality for the non-state-owned firms.

However, the situation has changed due to the government intervention. First, for the state-owned firms, the purpose of pyramiding is to help them to decentralize their firm decision rights to firm management without selling off their ownership (Fan et al., 2005), and the high bureaucratic costs associated with the pyramids deter ex-post intervention by the government (Williamson, 1985), it is thus expected that, with the increase of pyramidal layers, the managers of SOFs tend to have more discretion to determine the quality of their corporate reports. The abundant resource and political legitimacy might make SOFs having the least need to use CSR reporting to seek preferred status and associated resources from the government (Ma and Parish, 2006; Li and Zhang, 2007; Marquis and Qian, 2014). However, the executives of SOFs concurrently hold the administrative position in the government departments and bureaus (Fan et al., 2007). Given the government control on the political promotion and personal dismissal, the executives of SOFs with administrative position would have strong political incentives to publish CSR reporting in a substantive way to satisfy with the government requirement. Marquis and Qian (2014) provide evidence that firms whose leaders hold positions as government officials are more likely to engage in high quality CSR reporting, mitigating the relevance of pyramidal layers to the CSR reporting. Due to the multiple functions that state-owned firms play in the social and economic life, the effect of pyramidal layer on the reporting quality is unclear. Thus, we posit the following hypotheses:

H1a: For the non-state-owned firms, CSR reporting quality is negatively associated with the number of pyramid layers.

H1b: For the state-owned firms, the relationship between CSR reporting quality and number of pyramid layer is unclear.

The pyramidal structure also creates a separation in control rights and ownership stake, which allows the top owners to commit low equity investment while maintaining tight control of the firm. When an owner effectively controls a firm, he/she also controls the production of the firm's information and reporting policies. Fan and Wong (2002) argues that when the ultimate owner becomes entrenched with high levels of control, outside investors pay less attention to the reported accounting information because they anticipate that the controlling owner reports accounting information out of self-interest rather than as a reflection of the firm's true underlying economic transaction. Thus, accounting informativeness is significantly and negatively related to the degree of divergence between the ultimate owner's control and the equity ownership level. Due to the externality of CSR, with the increase in the degree of separation between the ultimate owner's control rights and ownership rights, the ultimate owner of NSOFs would limit the bottom firm to invest in CSR activities and report CSR information out of selfinterest.

For the state-owned firms with the exclusive political connection with the government, however, they have better access to resources which help them to engage CSR activities and prepare CSR reporting in a substantive way. In addition, CSR reporting is a political signal that is utilized by the government to create norms of legitimacy (Dobbin and Sutton, 1998; Marquis and Qian, 2014). The ultimate state owner may use their exceeding control rights to guide the bottom firm to report better CSR reports in response to the government signal. Thus, we posit the following hypotheses:

H2a: For the non-state-owned firms, CSR reporting quality is negatively related to the degree of control-ownership rights separation.

H2b: For the state-owned firms, CSR reporting quality is positively related to the degree of control-ownership rights separation. 


\section{RESEARCH METHODOLOGY}

\subsection{Sample and Data Collection}

Our initial sample consists of all Chinese listed A-share firms that received a CSR reporting quality score during 2010-2012 from the Rankins (RKS) Inc., a private and professional China-specific CSR rating agency established in Beijing. Rankins evaluates CSR reporting quality by using Structured Experts Scoring Method to conduct a comprehensive evaluation from the following four dimensions: macrocosm (M, 30\%), content (C, 45\%), technique (T, 15\%), and industry characteristic (I, 10\%). The total of $\mathrm{M}, \mathrm{C}, \mathrm{T}$ and I dimension is the final score, which ranges from 0 to 100. The higher score, the higher the CSR reporting quality is. In addition, the RKS database also provides a CSR report rating rank ranging from the lowest (C) to the highest (AAA) level. Each level can be marginally adjusted by using "-." and "+" except the AAA and CCC and lower levels. We numbered the lowest level "C" as " 1 ", "CC" as " 2 , up to the highest "AAA" as " 20 ". Thus, we use rating score and reporting rank as the proxies of dependent variable reporting quality (CSRR), respectively.

We firstly exclude firms listed on the Growth Enterprises Market (GEM) due to the particularity of the regulation on these firms. Secondly, we exclude firms falling in the finance industry due to the regulation and the particularity of operation. We then manually collect the ownership structure information from the annual reports of sample firms, which are available from the official websites of the Shanghai Stock Exchange (http://www.sse.com.cn) and the Shenzhen Stock Exchange (http://www.szse.cn). Our final sample consists of 1388 reports after excluding the sample firms that have missing value.

Table 1. Sample Industry Distribution

\begin{tabular}{|c|c|c|c|c|c|c|c|c|}
\hline \multirow{2}{*}{ Industry } & \multicolumn{2}{|c|}{2010} & \multicolumn{2}{|c|}{2011} & \multicolumn{2}{|c|}{2012} & \multicolumn{2}{|c|}{ Sub-Total } \\
\hline & $\mathbf{N}$ & $(\%)$ & $\mathbf{N}$ & $(\%)$ & $\mathbf{N}$ & $(\%)$ & $\mathbf{N}$ & $(\%)$ \\
\hline Agriculture, Forestry, Fishing \& Hunting & 5 & $(1.18)$ & 8 & $(1.75)$ & 9 & $(1.76)$ & 22 & $(1.59)$ \\
\hline Mining & 26 & $(6.16)$ & 24 & $(5.26)$ & 29 & $(5.69)$ & 79 & $(5.69)$ \\
\hline Food \& Beverage & 15 & $(3.55)$ & 14 & $(3.07)$ & 21 & $(4.12)$ & 50 & $(3.60)$ \\
\hline Textile, Apparel \& Leather & 10 & $(2.37)$ & 12 & $(2.63)$ & 15 & $(2.94)$ & 37 & $(2.66)$ \\
\hline Paper \&Printing & 9 & $(2.13)$ & 8 & $(1.75)$ & 11 & $(2.16)$ & 28 & $(2.02)$ \\
\hline Petroleum, Chemicals, Plastics \&Rubber & 30 & $(7.11)$ & 32 & $(7.02)$ & 39 & $(7.65)$ & 101 & $(7.28)$ \\
\hline Electrical Equipment & 17 & $(4.03)$ & 18 & $(3.95)$ & 18 & $(3.53)$ & 53 & $(3.82)$ \\
\hline Metal, Nonmetallic Mineral Product & 45 & $(10.66)$ & 49 & $(10.75)$ & 54 & $(10.59)$ & 148 & $(10.66)$ \\
\hline Machinery, Equipment \&Meter & 63 & $(14.93)$ & 72 & $(15.79)$ & 82 & $(16.08)$ & 217 & $(15.63)$ \\
\hline Pharmacy, Biology Product & 25 & $(5.92)$ & 26 & $(5.70)$ & 27 & $(5.29)$ & 78 & $(5.62)$ \\
\hline Other Machinery & 5 & $(1.18)$ & 5 & $(1.10)$ & 5 & $(0.98)$ & 15 & $(1.08)$ \\
\hline Electricity, Gas \&Water Supply & 23 & $(5.45)$ & 24 & $(5.26)$ & 26 & $(5.10)$ & 73 & $(5.26)$ \\
\hline Construction & 13 & $(3.08)$ & 13 & $(2.85)$ & 15 & $(2.94)$ & 41 & $(2.95)$ \\
\hline Transport Storage & 31 & $(7.35)$ & 35 & $(7.68)$ & 36 & $(7.06)$ & 102 & $(7.35)$ \\
\hline Information Technology & 26 & $(6.16)$ & 31 & $(6.80)$ & 31 & $(6.08)$ & 88 & $(6.34)$ \\
\hline Wholesale\& Retail & 21 & $(4.98)$ & 25 & $(5.48)$ & 26 & $(5.10)$ & 72 & $(5.19)$ \\
\hline Real Estate & 28 & $(6.64)$ & 29 & $(6.36)$ & 37 & $(7.25)$ & 94 & $(6.77)$ \\
\hline Social Service & 7 & $(1.66)$ & 8 & $(1.75)$ & 10 & $(1.96)$ & 25 & $(1.80)$ \\
\hline Communication\& Culture & 4 & $(0.95)$ & 4 & $(0.88)$ & 3 & $(0.59)$ & 11 & $(0.79)$ \\
\hline Conglomerate & 19 & $(4.50)$ & 19 & $(4.17)$ & 16 & $(3.14)$ & 54 & $(3.89)$ \\
\hline Total & 422 & & 456 & & 510 & & 1388 & \\
\hline
\end{tabular}

Table 1 presents the sample industry distribution. According to the CSRC industry classification (2001 Edition), there are 20 industries covered in this study. The Machinery, Equipment, and Meter industry provided the largest population of CSR reports with a total of 217 and accounts for $15.63 \%$ of all sample firms. The Metal, Nonmetallic Mineral Product industry follows with a percentage of $10.66 \%$. The Communication \& Culture industry provides the fewest reports with a total of 11 in four years, which accounts for only $0.79 \%$ of all reports. In addition, Table 1 also 
indicates that firms issuing CSR reports have increased steadily during the whole sample period, from 422 in 2010 to 510 in 2012.

\subsection{Measures}

\subsubsection{Explanatory Variables}

We consider two basic explanatory variables related to the pyramidal structure: pyramidal layer, and the degree of separation between control and ownership rights. Pyramidal layer (LAYER) is a numerical variable represented by the number of intermediate layers between the top ultimate owner and the bottom firm $i$ in a pyramid. The controlownership right separation (CO) refers to the ratio of ownership over control rights of the largest ultimate owner of firm $i$. Among them, control right $(\mathrm{C})$ is represented by the minimum of the shareholding percentage on the pyramidal chain between the top ultimate owner and the bottom firm $i$. Ownership right $(\mathrm{O})$ is represented by the ownership belonging to the top ultimate owner of firm $i$. All data related to the pyramidal structure are manually collected from the annual reports of sample firms.

\subsubsection{Control Variables}

Based on an extensive review of prior research, we select control variables that have been widely used in the CSR information disclosure field, including firm and industry characteristics and regulation environment (Cowen et al., 1987; Roberts, 1992; Gray et al., 2001; Cormier and Magnan, 2003; Al-Tuwaijri et al., 2004; Cormier et al., 2005; $\mathrm{Li}$ and Zhang, 2010). We first take firm characteristics such as ownership concentration, firm size, performance and financial risk as control variables. Ownership concentration $(\mathrm{OWN})$ is measured as the ownership right held by the largest shareholder ( $\mathrm{Li}$ and Zhang, 2010). Firm size (SIZE) is measured by the natural logarithm of total assets at prior year-end (Cowen et al., 1987; Roberts, 1992; Cormier and Magnan, 2003). Performance (ROA) is measured by return on assets at prior year-end (Cowen et al., 1987; Gray et al., 2001). Debt ratio is employed to proxy for financial risk (DEBT), and measured by the ratio of "total debt to total assets" at prior year-end (Roberts, 1992). Next, we select two dummy variables to reflect the regulation environment. The first one is mandatory regulation variable (REG), taking the value of "1"if firm $i$ is a member falling in the mandatory disclosure group in year $\mathrm{t}$, and "0" otherwise. Gray et al. (2001) argues that the failure to distinguish between mandatory and voluntary disclosure is a main reason that leads to an inconsistent result of prior studies. Further considering the potentially regulatory difference between Shenzhen Stock Exchange (SZSE) and Shanghai Stock Exchanges (SSE), we select the second dummy variable Exchange (EXC), taking the value of " 1 "if firm $i$ is listed on the SSE, and " 0 " otherwise. Last, following the previous research, we use two dummy variables to control for the potential influence of disclosure period, and use 19 dummy variables to capture the potential impact of different industries on CSR reporting quality (Cowen et al., 1987; Roberts, 1992). All data related to the financial statements and industry classifications are from the China Stock Market Accounting Research (CSMAR) database. The definition and measures of employed variables are summarized in Table 2. 
Table 2. Definition and Measurement of Variables

\begin{tabular}{|c|c|c|}
\hline Definition & Variables & Measure \\
\hline CSR reporting quality & CSRR & $\begin{array}{l}\text { Rating score available from RKS database, and Rating rank available } \\
\text { from RKS database }\end{array}$ \\
\hline Pyramidal layer & LAYER & $\begin{array}{l}\text { The number of intermediate layers between the top ultimate owner and the } \\
\text { bottom firm } i \text { in a pyramid }\end{array}$ \\
\hline Control-ownership right separation & $\mathrm{CO}$ & $\begin{array}{l}\text { Ratio of ownership over control rights of the largest ultimate owner of } \\
\text { firm } i\end{array}$ \\
\hline Ownership concentration & OWN & The ownership percentage held by the controlling shareholder \\
\hline Firm size & SIZE & The natural logarithm of total assets at prior year-end \\
\hline Performance & ROA & The ratio of net profit over total assets at prior year-end \\
\hline Financial risk & DEBT & The ratio of total debt to total assets at prior year-end \\
\hline Regulation & REG & $\begin{array}{l}\text { Dummy variable, taking the value of " } 1 \text { "if firm } i \text { is a member falling in } \\
\text { the mandatory group in year } t \text {, and " } 0 \text { " otherwise }\end{array}$ \\
\hline Exchange & EXC & $\begin{array}{l}\text { dummy variable, taking the value of " } 1 \text { "if firm } i \text { is listed on the Shanghai } \\
\text { Stock Exchange, and " } 0 \text { " otherwise }\end{array}$ \\
\hline Disclosure period & $\begin{array}{l}\text { Y2012 } \\
\text { Y2011 }\end{array}$ & $\begin{array}{l}\text { Two dummy variables to control for the potential influence of disclosure } \\
\text { period, taking the value of " } 1 \text { " if firm } i \text { issues CSR reporting in } 2012 \text { and } \\
2011 \text { respectively, and " } 0 \text { " otherwise }\end{array}$ \\
\hline Industry & $\mathrm{IND}_{j}$ & 19 dummy variables to control for the potential influence of industry \\
\hline
\end{tabular}

Equation (1) presents a generalized model for different specifications on the right hand side to test the proposed hypotheses:

$$
\operatorname{CSRR}_{i t}=\alpha+\sum \beta_{i t} \text { Explanatory Variables }_{i t}+\sum \gamma_{i t} \text { ControlVariables }_{i t}+\varepsilon
$$

where $C S R R_{i t}$ refers to the CSR Reporting quality, measured as rating score and rating rank of firm $i$ in year $t$, respectively; Explanatory Variables refers to the independent variables, including pyramidal layer (LAYER), and the degree of separation between control rights and ownership rights $(C O)$; Control Variables refer to ownership concentration $(\mathrm{OWN})$, firm size $(S I Z E)$, performance $(R O A)$, financial risk $(D E B T)$, regulation $(R E G)$, stock exchange $(E X C), 2$ variables labeled disclosure period, Y2012 and Y2011, and 19 industry dummy variables $\left(I N D_{j}\right)$; and $\varepsilon$ is the error term.

\section{EMPIRICAL RESULTS}

\subsection{Descriptive Statistics}

Table 3 and 4 present the descriptive statistics of CSR reporting quality during three sample years. Panel A in Table 3 shows an apparent increase in terms of the disclosure quality, ranging from 31.658 in 2010 to 35.987 in 2012 , with a yearly average increase of 1.86 (mean) and 1.41 (median). Panel B in Table 3 reports that CSR reporting quality scores of state-owned firms with an average of 34.065 is higher than that of non-state-owned firms.

Table 3. Descriptive Statistics of CSR Reporting Quality Score

\begin{tabular}{l|c|c|c|c|c|c|c}
\hline \multicolumn{1}{c|}{ Type } & Mean & $\begin{array}{c}\text { Std. } \\
\text { Deviation }\end{array}$ & Minimum & Maximum & $\mathbf{2 5}^{\text {th }}$ & $\begin{array}{c}\mathbf{5 0}^{\text {th }} \\
\text { Median) }\end{array}$ & $\mathbf{7 5}^{\text {th }}$ \\
\hline Panel A: By year & & & & & & & \\
\hline 2010 & 31.658 & 11.164 & 11.69 & 78.49 & 24.645 & 28.575 & 34.813 \\
\hline 2011 & 33.702 & 12.808 & 13.33 & 80.29 & 25.145 & 30.175 & 38.025 \\
\hline 2012 & 35.987 & 12.541 & 15.12 & 81.88 & 28.033 & 32.480 & 39.495 \\
\hline \\
Panel B: By ultimate owner \\
\hline SOFs & 34.065 & 12.377 & 13.33 & 80.29 & 25.893 & 30.650 & 37.345 \\
\hline NSOFs & 30.369 & 10.338 & 11.69 & 81.88 & 23.839 & 28.130 & 33.100 \\
\hline
\end{tabular}


The descriptive results in Table 4 further indicate that the number of CSR reports with A and B higher level of quality has been increasing over the sample period. In particular, there is almost $20 \%$ rise in the B or higher level in 2012. In Panel B, the percentage of firms with higher CSR reporting quality (A and B level) in the state-owned firms is obviously higher than that in non-state-owned firms.

Table 4. Descriptive Statistics of CSR Reporting Quality Rank

\begin{tabular}{|c|c|c|c|c|c|c|c|}
\hline \multirow{2}{*}{$\begin{array}{r}\text { Type } \\
\text { Panel A: By year }\end{array}$} & \multicolumn{2}{|c|}{ A or higher } & \multicolumn{2}{|c|}{ B or higher } & \multicolumn{2}{|c|}{ C or higher } & Total \\
\hline & & & & & & & \\
\hline 2010 & 21 & $(4.98 \%)$ & 289 & $(68.48 \%)$ & 112 & $(26.54 \%)$ & 422 \\
\hline 2011 & 28 & $(6.14 \%)$ & 283 & $(62.07 \%)$ & 145 & $(31.79 \%)$ & 456 \\
\hline 2012 & 30 & $(5.88 \%)$ & 416 & $(81.57 \%)$ & 64 & $(12.55 \%)$ & 510 \\
\hline
\end{tabular}

Panel B: By ultimate owner

\begin{tabular}{l|c|c|c|c|c|c|c} 
SOFs & 67 & $(7.17 \%)$ & 688 & $(73.66 \%)$ & 179 & $(19.16 \%)$ & 934 \\
\hline NSOFs & 12 & $(2.64 \%)$ & 300 & $(66.08 \%)$ & 142 & $(31.28 \%)$ & 454 \\
\hline
\end{tabular}

Notes: "A or higher" represents the CSR reporting rank belonging to A, AA and AAA and the levels marginally adjusted by using "-_" and "+"” for $\mathrm{A}, \mathrm{AA}$ and AAA; the same as "B or higher" and "C or higher".

Table 5 reports the distribution of pyramidal layers of sample firms. Results indicate that nearly $70 \%$ of sample firms are controlled by the state, which shows that the government is still the dominant owner of firms in China. $97 \%$ of sample firms have 2 or more layers between the top ultimate owner and the bottom firms, suggesting that the pyramid is a widespread ownership structure in China. In addition, for the state-owned firms, the percentage of firms having 2 layers accounts for the majority $(56.85 \%)$, while the non-state-owned firms having 3 layers account for the most part $(48.02 \%)$, and the percentage of firms having 4 or more layers of non-state-owned firms are higher than that of state-owned firms, suggesting that non-state-owned firms are more likely to build complicated pyramids than state-owned firms.

Table 5. Pyramidal Layers of State-owned Firms and Non-state-owned Firms

\begin{tabular}{|c|c|c|c|c|c|c|c|}
\hline \multirow{2}{*}{\multicolumn{2}{|c|}{ Type }} & \multicolumn{5}{|c|}{ Number of pyramidal layers } & \multirow{3}{*}{$\begin{array}{c}\text { Total } \\
934\end{array}$} \\
\hline & & \multirow{2}{*}{$\begin{array}{c}1 \\
28\end{array}$} & \multirow{2}{*}{$\begin{array}{c}\mathbf{2} \\
531\end{array}$} & \multirow{2}{*}{$\begin{array}{c}\mathbf{3} \\
273\end{array}$} & \multirow{2}{*}{\begin{tabular}{|c|}
4 \\
76
\end{tabular}} & \multirow{2}{*}{$\begin{array}{c}5 \text { or more } \\
26\end{array}$} & \\
\hline $\mathrm{SOFs}_{\mathrm{s}}$ & $\mathrm{N}$ & & & & & & \\
\hline SUFS & $(\%)$ & $(2.99)$ & $(56.85)$ & $(29.23)$ & $(8.14)$ & $(2.78)$ & $(100)$ \\
\hline \multirow{2}{*}{ NSOFs } & $\mathrm{N}$ & 18 & 98 & 218 & 65 & 55 & 454 \\
\hline & $(\%)$ & $(3.96)$ & $(21.59)$ & $(48.02)$ & $(14.32)$ & $(12.11)$ & $(100)$ \\
\hline \multirow{2}{*}{ Total } & $\mathrm{N}$ & 46 & 629 & 491 & 141 & 81 & 1388 \\
\hline & $(\%)$ & $(3.31)$ & $(45.32)$ & $(35.37)$ & $(10.16)$ & $(5.84)$ & $(100)$ \\
\hline
\end{tabular}

Note: The number of pyramidal layers is defined to be one when an ultimate owner directly controls the listed firm, two when there is one intermediate firm between the top ultimate owner and the bottom firm, and so on. The number of pyramidal layers is counted from the longest controlling chain in case of multiple chains.

Following Fan and Wong's study (2002), we take $20 \%$ and $50 \%$ as the cutoff of control rights and ownership rights. Panel A in Table 6 reports the distribution of control rights falling in the three intervals $(C<20 \% ; 20 \% \leq C<50 \%$; $50 \% \leq \mathrm{C})$. Although both SOFs and NSOFs have the most falling in the middle interval, there is a difference on the attitude to the bottom and upper intervals. SOFs are more likely to have absolute control on bottom firms than NSOFs, but NSOFs have a higher percentage in the bottom interval than SOFs. Panel B presents the distribution of ownership rights, which shows a similar distribution trend to that in Panel A. Panel C provides further evidence on the divergence between control rights and ownership rights. Results indicate that nearly two thirds of the SOFs do not have divergence between control rights and ownership at all $(\mathrm{CO}=1)$. However, this percentage for the NSOFs is only $28.41 \%$. Moreover, there are $24.22 \%$ of NSOFs with CO separation lower than 0.5 , significantly higher than that of SOFs. The divergence between control rights and ownership rights in the NSOFs is more serious than that in the SOFs. 
Table 6. Descriptive Statistics of Control Rights, Ownership Rights and CO Separation

\begin{tabular}{|c|c|c|c|c|}
\hline \multicolumn{5}{|c|}{ Panel A: Control Right } \\
\hline & & $\mathrm{C}<20 \%$ & $20 \% \leqslant C<50 \%$ & $50 \% \leqslant C$ \\
\hline \multirow{2}{*}{ SOFs } & $\mathrm{N}$ & 72 & 499 & 363 \\
\hline & $(\%)$ & $(7.71)$ & $(53.43)$ & (38.86) \\
\hline \multirow{2}{*}{ NSOFs } & $\mathrm{N}$ & 88 & 264 & 102 \\
\hline & $(\%)$ & (19.38) & $(58.15)$ & $(22.47)$ \\
\hline \multirow{2}{*}{ Total } & $\mathrm{N}$ & 160 & 763 & 465 \\
\hline & $(\%)$ & (11.53) & $(54.97)$ & $(33.50)$ \\
\hline
\end{tabular}

Panel B: Ownership Right

\begin{tabular}{|c|c|c|c|c|}
\hline & & $O<20 \%$ & $20 \% \leqslant 0<50 \%$ & $50 \% \leqslant 0$ \\
\hline \multirow{2}{*}{ SOFs } & $\mathrm{N}$ & 161 & 488 & 285 \\
\hline & $(\%)$ & $(17.24)$ & $(52.25)$ & $(30.51)$ \\
\hline \multirow{2}{*}{ NSOFs } & $\mathrm{N}$ & 194 & 206 & 54 \\
\hline & $(\%)$ & $(42.73)$ & $(45.37)$ & $(11.89)$ \\
\hline \multirow{2}{*}{ Total } & $\mathrm{N}$ & 355 & 694 & 339 \\
\hline & $(\%)$ & $(25.58)$ & $(50.00)$ & $(24.42)$ \\
\hline
\end{tabular}

Panel C: The Ratio of Ownership over Control Rights

\begin{tabular}{|c|c|c|c|c|}
\hline & & $\mathrm{CO}<0.5$ & $0.5 \leqslant \mathrm{CO}<1$ & $\mathrm{CO}=1$ \\
\hline \multirow{2}{*}{ SOFs } & $\mathrm{N}$ & 75 & 225 & 634 \\
\hline & $(\%)$ & $(8.03)$ & $(24.09)$ & $(67.88)$ \\
\hline \multirow{2}{*}{ NSOFs } & $\mathrm{N}$ & 109 & 216 & 129 \\
\hline & $(\%)$ & $(24.01)$ & $(47.58)$ & $(28.41)$ \\
\hline \multirow{2}{*}{ Total } & $\mathrm{N}$ & 184 & 441 & 763 \\
\hline & $(\%)$ & $(13.26)$ & $(31.77)$ & $(54.97)$ \\
\hline
\end{tabular}

Notes: Control right $(\mathrm{C})$ is represented by the minimum of the shareholding percentage on the pyramidal chain between the top ultimate owner and the bottom firm $i$. Ownership right $(\mathrm{O})$ is represented by the ownership belonging to the top ultimate owner of firm $i$. The control-ownership right separation $(\mathrm{CO})$ refers to the ratio of ownership over control rights of the largest ultimate owner of firm $i$.

Table 7 provides distributional characteristics for the variables employed in the study with the exception of the dummy variable proxies for industry and disclosure period. As shown in Table 7, CSR reporting score averages 33.92 (out of a possible full score 100), with a median score of 30.73, which shows that CSR reporting quality of Chinese listed firms is relatively low. The average ownership concentration is approximately $41.34 \%$, indicating a higher concentration of Chinese listed firms. The average pyramidal layer between listed firms and their ultimate owners is 2.73 with a median of 3 , indicating that pyramidal structure is very popular in companies listed on the Chinese capital market, consistent with prior research (Fan et al. 2005). The mean value of CO is 0.83, a little larger divergence than that of East Asian firms in Fan and Wong's study (2002). 
Table 7. Descriptive Statistics and Pearson Correlation Coefficients of Variables

\begin{tabular}{l|l|l|l|l|l|l|l|l|l|l}
\hline Variables & Mean & Median & CSRR & LAYER & CO & OWM & SIZE & ROA & DEBT & REG \\
\hline CSRR & 33.92 & 30.73 & 1 & & & & & & & \\
\hline LAYER & 2.73 & 3 & $-0.143^{* * *}$ & 1 & & & & & \\
\hline CO & 0.83 & 1 & $0.074^{* * *}$ & $-0.546^{* * *}$ & 1 & & & & \\
\hline OWN & 41.34 & 41.49 & $0.216^{* * *}$ & $-0.051^{*}$ & $0.226^{* * *}$ & 1 & & & & \\
\hline SIZE & 22.75 & 22.62 & $0.477^{* * *}$ & $-0.161^{* * *}$ & $0.125^{* * *}$ & $0.324^{* * *}$ & 1 & & & \\
\hline ROA & 0.07 & 0.06 & $0.064^{* *}$ & 0.043 & $-0.074^{* * *}$ & $0.065^{* *}$ & $-0.067^{* *}$ & 1 & & \\
\hline DEBT & 0.51 & 0.52 & $0.046^{*}$ & -0.010 & -0.001 & 0.013 & $0.429^{* * *}$ & $-0.403^{* * *}$ & 1 & \\
\hline REG & 0.72 & 1 & $0.115^{* * *}$ & $-0.070^{* * *}$ & 0.002 & 0.010 & $0.365^{* * *}$ & -0.043 & $0.153^{* * *}$ & 1 \\
\hline EXC & 0.62 & 1 & 0.022 & -0.014 & -0.006 & $0.057^{* *}$ & $0.174^{* * *}$ & $-0.146^{* * *}$ & $0.158^{* * *}$ & $0.376^{* * *}$ \\
\hline
\end{tabular}

Notes: ${ }^{1}$ CSRR in Table 7 is measured as rating score. Min refers to the minimum, and Max refers to the maximum. We also correlate the CSRR measured as Rating rank and other variables and results are consistent with those reported in Table 7. Due to the space limitation, we do not present the correlation results in the paper, but available from the authors upon request.

2. $* \mathrm{p}<0.10 ; * * \mathrm{p}<0.05 ; * * * \mathrm{p}<0.01$ respectively, based on a two-tailed t-test.

With respect to the control variables, the firm size averages 22.75 with a median 22.62 , the average ROA of sample firms is approximately $7 \%$, and the average debt ratio for sample firms is nearly $51 \%$. $72 \%$ of CSR reports are subject to the mandatory disclosure requirement. The willingness of Chinese firms to disclose CSR voluntarily is still very low. There are $62 \%$ of sample firms listed on the Shanghai Stock Exchange.

Table 7 also provides a correlation matrix for the dependent variable (measured as rating score), all independent variables and some control variables used in the study. Two selected independent variables are significantly related to the dependent variable CSRR. The highest correlation coefficient is 0.546 between pyramidal layer and controlownership right separation, lower than the critical value 0.8 , suggesting that multicollinearity is not a serious issue. The correlations between the control variables are relatively weak $(p \leq 0.40)$, except for the correlation between SIZE and DEBT $(p=0.429)$, and DEBT and ROA $(p=-0.403)$. We also checked for multicollinearity by looking at the VIFs (variance inflation factor). The VIFs are smaller than 2, mitigating the multicollinearity concerns.

\subsection{Regression Analysis}

Table 8 reports the multivariate regression results. Panel A uses the rating score to measure the dependent variable. Results indicate that pyramidal structure has a significant influence on the CSR reporting quality score mainly through the pyramidal layers. Regarding the key factor that influences CSR reporting quality, differences exists between SOFs and NSOFs. Specifically, the number of pyramidal layer is negatively related to the CSR reporting quality, particularly significant for the non-state-owned firms. H1a is supported. For the SOFs sample firms, the relation between pyramidal layer and CSR reporting quality is insignificant, as a result of the complexity of corporate governance in the state-owned firms. The divergence between control rights and ownership rights has a different effect on CSR reporting quality in the SOFs and NSOFs sample group. We use the ratio of ownership over control rights to measure the control-ownership rights separation. The lower the value of $\mathrm{CO}$, the higher degree the separation between control rights and ownership rights is. Thus, the negative coefficient of CO variable in the stateowned firm sub-samples means that the separation between control rights and ownership rights is significantly and positively related to the CSR reporting quality, supporting the hypothesis H2b. For non-state-owned firms, however, the relation between the CSR reporting quality and CO divergence is insignificant, and $\mathrm{H} 2 \mathrm{a}$ is not supported. 
Table 8. Multivariate regression results for the relation between pyramidal structure and CSR reporting quality

\begin{tabular}{|c|c|c|c|c|c|c|}
\hline \multicolumn{7}{|c|}{ Panel A: dependent variable - rating score } \\
\hline \multirow[b]{2}{*}{ Variables } & \multicolumn{2}{|c|}{ Full sample } & \multicolumn{2}{|c|}{ NSOFs } & \multicolumn{2}{|c|}{ SOFs } \\
\hline & $\begin{array}{c}\text { Parameter } \\
\text { estimate }\end{array}$ & t-statistic & $\begin{array}{c}\text { Parameter } \\
\text { estimate }\end{array}$ & t-statistic & $\begin{array}{c}\text { Parameter } \\
\text { estimate }\end{array}$ & t-statistic \\
\hline LAYER & $-1.001 * * *$ & -3.021 & $-1.033^{* *}$ & -2.141 & -0.655 & -1.399 \\
\hline $\mathrm{CO}$ & -2.186 & -1.485 & 1.203 & 0.547 & $-5.102 * * *$ & -2.409 \\
\hline OWN & 0.019 & 0.991 & -0.012 & -0.416 & 0.041 & 1.503 \\
\hline SIZE & $4.597 * * *$ & 17.364 & $4.740 * * *$ & 8.794 & $4.739 * * *$ & 14.553 \\
\hline ROA & -3.221 & 0.609 & -10.844 & -1.325 & -0.739 & -0.105 \\
\hline DEBT & $-9.143 * * *$ & -4.660 & $-5.572 *$ & -1.761 & $-9.558 * * *$ & -3.581 \\
\hline REG & $-1.838^{* *}$ & -2.511 & -1.385 & -1.120 & -1.196 & -1.198 \\
\hline EXC & $-1.107 *$ & -1.703 & $-2.779 * *$ & -2.511 & 0.237 & 0.277 \\
\hline Y2012 & $2.869 * * *$ & 4.135 & $1.935^{*}$ & 1.677 & $3.023 * * *$ & 3.467 \\
\hline Y2011 & $1.291 *$ & 1.828 & 0.227 & 0.196 & $1.757 * *$ & 1.989 \\
\hline $\mathrm{IND}_{\mathrm{i}}$ & Control & & Control & & Control & \\
\hline $\operatorname{Adj} . R^{2}$ & 0.295 & & 0.258 & & 0.297 & \\
\hline$N$ & 1338 & & 454 & & 934 & \\
\hline
\end{tabular}

Panel B: dependent variable - rating rank

\begin{tabular}{|c|c|c|c|c|c|c|}
\hline \multirow[b]{2}{*}{ Variables } & \multicolumn{2}{|c|}{ Full sample } & \multicolumn{2}{|c|}{ NSOFs } & \multicolumn{2}{|c|}{ SOFs } \\
\hline & $\begin{array}{c}\text { Parameter } \\
\text { estimate }\end{array}$ & t-statistic & $\begin{array}{c}\text { Parameter } \\
\text { estimate }\end{array}$ & t-statistic & $\begin{array}{c}\text { Parameter } \\
\text { estimate }\end{array}$ & t-statistic \\
\hline LAYER & $-0.248 * * *$ & -2.678 & $-0.283 * *$ & -2.053 & -0.114 & -0.883 \\
\hline $\mathrm{CO}$ & $-0.727^{*}$ & -1.769 & 0.177 & 0.283 & $-1.511 * *$ & -2.578 \\
\hline OWN & 0.004 & 0.775 & -0.005 & -0.629 & 0.009 & 1.177 \\
\hline SIZE & $1.253 * * *$ & 16.957 & $1.345 * * *$ & 8.746 & $1.283 * * *$ & 14.240 \\
\hline ROA & -0.387 & -0.262 & -2.752 & -1.178 & 0.669 & 0.345 \\
\hline DEBT & $-2.495 * * *$ & -4.555 & $-1.436^{*}$ & -1.591 & $-2.624 * * *$ & -3.553 \\
\hline REG & $-0.476^{* *}$ & -2.330 & -0.474 & -1.344 & -0.300 & -1.087 \\
\hline $\mathrm{EXC}$ & $-0.317^{*}$ & -1.746 & $-0.875 * * *$ & -2.772 & -0.008 & -0.034 \\
\hline Y2012 & $0.811^{* * *}$ & 4.189 & $0.600^{*}$ & 1.823 & $0.805^{* * *}$ & 3.335 \\
\hline Y2011 & 0.265 & 1.344 & -0.113 & -0.343 & $0.424 *$ & 1.734 \\
\hline $\mathrm{IND}_{\mathrm{i}}$ & Control & & Control & & Control & \\
\hline $\operatorname{Adj} \cdot R^{2}$ & 0.294 & & 0.264 & & 0.293 & \\
\hline$N$ & 1338 & & 454 & & 934 & \\
\hline
\end{tabular}

Note: ${ }^{*} \mathrm{p}<0.10 ;{ }^{* *} \mathrm{p}<0.05 ; * * \mathrm{p}<0.01$.

We also take CSR reporting quality rating rank as the dependent variable to make regression and results are reported in Panel B of Table 8. Results of Panel B are basically consistent with those in Panel A except for the variable of the divergence between control rights and ownership rights in the full sample, which is marginally significant and negatively related to the CSR reporting rating rank.

Most selected control variables show the same effect on CSR reporting quality in Panels A and B, by using CSR reporting quality score and rank as dependent variables respectively. Specially, firm size is significantly and positively related to the CSRR at the level of $1 \%$, providing evidence that larger firms are more likely to disclose high-quality CSR reports. DEBT is significantly and negatively related to CSR reporting score in all models. Two disclosure period control variables are positively related to CSRR, indicating that the reporting quality increases over the sample period. As for the relationship between regulation and CSR reporting quality, both mandatory requirement and exchange are negatively related to the reporting quality in the full sample. In the sub-samples, however, only exchange is significantly negative in the non-state-owned firm sample, suggesting that regulation does not necessarily bring a good quality report. The coefficients of performance (ROA) are not significant in all models, suggesting that firm profitability is not an important factor on influencing CSR reporting quality. The control variable of ownership concentration, measured as the ownership percentage held by the controlling shareholder, does not have a significant influence on CSR reporting quality in general. 
We also conduct the following robustness tests. First, we use the ownership rights held by the top ultimate owner to proxy the ownership concentration. Results are reported in Table 9, which are consistent with those in Table 8.

Table 9. Regression results for tests of the relation between pyramidal structure and CSR reporting quality

\begin{tabular}{|c|c|c|c|c|c|c|}
\hline \multicolumn{7}{|c|}{ Panel A: dependent variable - rating score } \\
\hline \multirow[t]{2}{*}{ Variables } & \multicolumn{2}{|c|}{ Full sample } & \multicolumn{2}{|c|}{ NSOFs } & \multicolumn{2}{|c|}{ SOFs } \\
\hline & $\begin{array}{c}\text { Parameter } \\
\text { estimate }\end{array}$ & t-statistic & $\begin{array}{c}\text { Parameter } \\
\text { estimate }\end{array}$ & t-statistic & $\begin{array}{c}\text { Parameter } \\
\text { estimate }\end{array}$ & t-statistic \\
\hline LAYER & $-0.975 * * *$ & -2.959 & $-1.037^{* *}$ & -2.172 & -0.622 & -1.333 \\
\hline $\mathrm{CO}$ & -2.510 & -1.408 & 1.912 & 0.745 & $-6.391 * *$ & -2.519 \\
\hline OWN & 0.014 & 0.638 & -0.023 & -0.638 & 0.038 & 1.316 \\
\hline SIZE & $4.624 * * *$ & 17.423 & $4.736^{* * *}$ & 8.894 & $4.754 * * *$ & 14.533 \\
\hline ROA & -3.143 & -0.594 & -10.688 & -0.061 & -0.659 & -0.094 \\
\hline DEBT & $-9.214 * * *$ & -4.691 & $-5.536^{*}$ & -1.749 & $-9.635^{* * *}$ & -3.609 \\
\hline REG & $-1.876^{* *}$ & -2.562 & -1.434 & -1.168 & -1.199 & -1.200 \\
\hline EXC & $-1.099 *$ & -1.687 & $-2.812 * *$ & -2.538 & 0.221 & 0.258 \\
\hline Y2012 & $2.854 * * *$ & 4.113 & $1.948^{*}$ & 1.691 & $3.023 * * *$ & 3.465 \\
\hline Y2011 & $1.281^{*}$ & 1.813 & 0.241 & 0.209 & $1.759 * *$ & 1.989 \\
\hline $\mathrm{IND}_{\mathrm{i}}$ & Control & & Control & & Control & \\
\hline Adj. $R^{2}$ & 0.294 & & 0.259 & & 0.296 & \\
\hline$N$ & 1338 & & 454 & & 934 & \\
\hline
\end{tabular}

Panel B: dependent variable - rating rank

\begin{tabular}{|c|c|c|c|c|c|c|}
\hline \multirow[t]{2}{*}{ Variables } & \multicolumn{2}{|c|}{ Full sample } & \multicolumn{2}{|c|}{ NSOFs } & \multicolumn{2}{|c|}{ SOFs } \\
\hline & $\begin{array}{c}\text { Parameter } \\
\text { estimate }\end{array}$ & t-statistic & $\begin{array}{c}\text { Parameter } \\
\text { estimate }\end{array}$ & t-statistic & $\begin{array}{c}\text { Parameter } \\
\text { estimate }\end{array}$ & t-statistic \\
\hline LAYER & $-0.243 * * *$ & -2.636 & $-0.289^{* *}$ & -2.118 & -0.108 & -0.835 \\
\hline $\mathrm{CO}$ & -0.814 & -1.637 & 0.356 & 0.487 & $-1.805^{* *}$ & -2.572 \\
\hline OWN & 0.003 & 0.556 & -0.007 & -0.647 & 0.009 & 1.068 \\
\hline SIZE & $1.258 * * *$ & 16.979 & $1.338 * * *$ & 8.804 & $1.285^{* * *}$ & 14.202 \\
\hline ROA & -0.371 & -0.251 & -2.740 & -1.173 & 0.686 & 0.354 \\
\hline DEBT & $-2.507 * * *$ & -4.571 & -1.429 & -1.583 & $-2.637 * * *$ & -3.569 \\
\hline REG & $-0.483 * *$ & -2.361 & -0.470 & -1.340 & -0.300 & -1.084 \\
\hline EXC & $-0.316^{*}$ & -1.739 & $-0.879 * * *$ & -2.779 & -0.006 & 0.027 \\
\hline Y2012 & $0.809^{* * *}$ & 4.175 & $0.608^{*}$ & 1.849 & $0.805^{* * *}$ & 3.335 \\
\hline Y2011 & 0.263 & 1.334 & -0.106 & -0.322 & $0.425^{*}$ & 1.736 \\
\hline IND $_{i}$ & Control & & Control & & Control & \\
\hline $\operatorname{Adj} . R^{2}$ & 0.293 & & 0.264 & & 0.292 & \\
\hline$N$ & 1338 & & 454 & & 934 & \\
\hline
\end{tabular}

Next, we replace ROA with ROCE (Return on Capital Employed) as the proxy for firms' profitability, and use a dummy variable to represent the environment-sensitive industry. Environment-sensitive industry is defined according to the Guideline to Environmental Information Disclosure of Listed Firms issued by The Ministry of Environmental Protection (MEP) of China in September 2010. This document defines 16 industries, including industries such as textile, mining, and pharmacy etc. as environment-sensitive industries. In our sample, about $37 \%$ of sample firms fall into the environmental-sensitive profile. The multivariate regression results are also consistent with the prior findings.

In addition, La Porta et al. (1999) argues that a firm's ownership structure is pyramidal if (1) it has an ultimate owner, and (2) there is at least one publicly traded company between it and the ultimate owner in the chain of 20 percent control right. We also use the final sample that excludes observations with $\mathrm{C}<20 \%$ and use the sub-sample that excludes both $\mathrm{C}<20 \%$ and $\mathrm{C} \geq 50 \%$ to make regression respectively, the results still hold. 
Last, we also measure the control-ownership rights separation as the difference between the control rights and ownership rights held by the ultimate owner to replace the ratio of ownership rights over control rights, the results keep consistently.

\section{SUMMARY AND CONCLUSIONS}

The goal of this paper is to investigate the development of CSR reports in China, and the impact of corporate pyramidal structure on CSR reporting quality. The descriptive results indicate that the quality of CSR reporting of Chinese firms is still very low, but has been improved slowly over the sample period. Moreover, the state-owned firms provide CSR reporting with a higher quality than their peer non-state-owned firms, when measured by using either CSR reporting score or rating rank.

In terms of the pyramidal structure, we find that the pyramidal structure has been widely employed by Chinese firms, with $97 \%$ of sample firms having 2 or more layers between the top ultimate owner and bottom firms. There are approximate $45 \%$ sample firms with CO ratio unequal to 1, suggesting that the separation of control right and ownership stake is not as serious as the pyramiding. Considering the political interference further, however, our results demonstrate that NSOFs are more likely to build pyramids with 3 or more layers, while SOFs are more likely to build pyramids with 2 layers. The separation of ownership and control is most pronounced among NSOFs. For the SOFs, there are nearly $33 \%$ state-owned firms separating their control rights from ownership, while $72 \%$ NSOFs separate their control rights from ownership effectively.

Regarding the relationship between pyramidal structure and CSR reporting quality, we can draw the following conclusions. First, CSR reporting quality is negatively influenced by the pyramidal layer between the pyramidal top firm and bottom firm, suggesting that the less the pyramidal layer between the top ultimate owner and bottom firms, the better the CSR reporting quality. Second, regarding the relation between CSR reporting quality and the degree of divergence between control and ownership rights, results indicates a negative relation for the non-state-owned firms, but insignificant.

In addition, we also find evidence on the political interference on the relationship between pyramidal structure and CSR reporting quality. The significant negative relationship between the number of pyramidal layers and CSR reporting quality disappears in the state-owned firms. And the insignificant effect of the separation of control rights and ownership on CSR reporting quality becomes significant. The separation of control rights and ownership is positively related to the CSR reporting quality for the state-owned firms, which can exert more pressure on corporate managers to report CSR through the excess of control right over ownership. This has public policy implications for China as well as a number of other countries in the Asia-Pacific region.

It is necessary to acknowledge, however, that certain limitations exist. First, more empirical evidence is needed to test the relationship between pyramidal structure and CSR reporting. Although this paper provides some descriptive analysis on pyramidal structure and the development of CSR reporting in Chinese market, empirical test is inadequate. Second, the political interference only focuses on comparison between the state-owned firms and nonstate-owned firms. In order to observe the complete effect of political interference on the relationship, it would be better that the political position of entrepreneurs and the political legacy of firms would be taken into account in the future research.

\section{AUTHOR BIOGRAPHIES}

Jianling Wang, Ph.D., is an associate professor in the School of Management at Xi'an Jiaotong University in China. Her main research interests include CSR information disclosure and financial reporting quality. E-mail: wangj1@mail.xjtu.edu.cn

Min Zhou, is a doctorate student at Virginia Tech in U. S. A. His research interests include accounting information system and corporate social responsibility. E-mail: mizhou@vt.edu 
Lijun Lei, is a doctorate student at Virginia Tech in U.S.A. His research interests include accounting information system and corporate social responsibility. E-mail: 1lei1@vt.edu

Weiguo Fan Ph. D., is an accounting professor at the Department of Accounting and Information Systems of Virginia Tech in U. S. A. His research interests include big data, corporate social responsibility and information system. E-mail: wfan@vt.edu

\section{ACKNOWLEDGEMENTS}

Jianling Wang gratefully acknowledges the financial support from Natural Science Foundation Committee of China (Project number: 71202077) and the Fundamental Research Funds for the Central Universities (Grant number: SK2015006).

\section{REFERENCE}

Aguilear R.V., Williams, C.A., Conley, J.M., \& Ripp, D.E. (2006). Corporate governance and social responsibility: A comparative analysis of the UK and the US. Corporate Governance and Social Responsibility, 14(3): 147-158.

Al-Tuwaijri, S.A., Christensen, T.E., \& Hughes II., K.E. (2004). The relations among environmental disclosure, environmental performance, and economic performance: A simultaneous equations approach. Accounting, Organizations and Society, 29(5\&6): 447-471.

Buhr, N., \& Freedman, M. (2001). Culture, institutional factors and differences in environmental disclosure between Canada and the United States. Critical Perspectives on Accounting, 12(3): 293-322.

Cadbury Code. (1992). Report of the committee on the financial aspects of corporate governance: The code of best practice, Gee Professional Publishing, London.

Chau, G.K., \& Gray, S.J. (2002). Ownership structure and corporate voluntary disclosure in Hong Kong and Singapore. International Journal of Accounting, 27: 247-265.

China WTO Tribune. (2009). Four discoveries of the research on CSR reports in China from 2001 to 2009. [in Chinese]. http://www.wtoguide.net/Html/tbgz/061225155710689550912738279331.html

Claessens, S., Djankov, S., \& Lang, L.H.P. (2000). The separation of ownership and control in East Asian corporations. Journal of Financial Economics, 58(1-2): 81-112.

Cormier, D., \& Magnan, M. (2003). Environmental reporting management: A continental European perspective. Journal of Accounting and Public Policy, 22(1): 43-62.

Cormier, D., Magnan, M., \& Velthoven, B. V. (2005). Environmental disclosure quality in large German companies: Economic incentives, public pressures or institutional conditions? European Accounting Review, 14(1): 3-39.

Cowen, S.S., Ferreri, L.B., \& Parker, L.D. (1987). The impact of corporate characteristics on social responsibility disclosure: A typology and frequency-based analysis. Accounting, Organizations and Society, 12(2): 111-122.

Dobbin, F., \& Sutton, F.R. (1998). The strength of a weak state: the rights revolution and the rise of human resources management divisions. The American Journal of Sociology, 104(2): 441-476.

Eurosif and ACCA. (2013). What do investors expect from non-financial reporting? http://www.eurosif.org Accessed January 29, 2014.

Faccio, M., \& Lang, L.H.P. (2002) The ultimate ownership of western European corporations. Journal of Financial Economics, 65(3): 365-395.

Fan, J.P.H., \& Wong, T.J. (2002). Corporate ownership structure and the informativeness of accounting earnings in East Asia. Journal of Accounting and Economics, 33(3): 401-25.

Fan, J. P.H., Wong, T.J., \& Zhang, T. (2005). The emergence of corporate pyramids in China. SSRN working paper.

Fan, J.P.H., Wong, T.J., \& Zhang, T. (2007). Politically connected CEOs, corporate governance and post-IPO performance of China's partially privatized firms. Journal of Financial Economics, 84: 330-357.

Fan, J.P.H., Wong, T.J., \& Zhang, T. (2012). Institutions and organizational structure: The case of state-owned corporate pyramids. The Journal of Law, Economics, and Organization, 29(6): 1217-1252.

Ghazali, N.A.M. (2007). Ownership structure and corporate social responsibility disclosure: Some Malaysian evidence. Corporate Governance, 7(3): 251-266.

Gray, R., Javad, M., Power D.M., \&Sinclair, C.D. (2001). Social and environmental disclosure and corporate characteristics: A research note and extension. Journal of Business Finance \& Accounting, 28(3\&4): 327-356.

Haniffa, R.M., \& Cooke, T.E. (2005). The impact of culture and governance on corporate social reporting. Journal of Accounting and Public Policy, 24(5):391-430.

Hendarto, H.A., \& Purwanto, B.M. (2012). Market reactions of mandatory implementation of corporate social responsibility: Indonesia context. Asia Pacific Management Review, 17(4): 379-402. 
Holder-Webb, L., Cohen, J.R., Nath, L., \& Wood, D. (2009). The supply of corporate social responsibility disclosures among U.S. firms. Journal of Business Ethics, 84(4): 497-527.

KPMG International. (2014). The KPMG survey of corporate social responsibility reporting 2013. http: //www.kpmg.com/sustainability.

La Porta, R., Lopez-de-Silanes, F., \& Shleifer, A. (1999). Corporate ownership around the world. The Journal of Finance, 54(2): 471-517.

Li, W., \& Zhang, R. (2010). Corporate social responsibility, ownership structure, and political interference: Evidence from China. Journal of Business, 96: 631-645.

Li. H., \& Zhang, Y. (2007). The role of managers' political networking and functional experience in new venture performance: Evidence from China's transition economy. Strategic Management Journal, 28(8): 791-804.

Ma, D., \& Parish, W.L. (2006). Tocquevillian moments: charitable contributions by Chinese private entrepreneurs. Social Forces, 85(2): 943-964.

Mahoney, L.S., Thorne, L., Cecil, L., \& LaGore, W. (2013). A research note on standalone corporate social responsibility reports: signaling or greenwashing? Critical Perspectives on Accounting, 24(4-5): 350-359.

Marquis, C., \& Qian, C. (2014). Corporate social responsibility reporting in China: Symbol or Substance? Organization Science, 25(1): $127-148$

Roberts, R.W. (1992). Determinants of corporate social responsibility disclosure: An application of stakeholder theory. Accounting, Organizations and Society, 17(6): 595-612.

Wang, P., Wang, F., Zhang, J., \& Yang, B. (2012). The effect of ultimate owner and regulation policy on corporate social responsibility information disclosure: Evidence from China. African Journal of Business Management, 6(20): 61836193.

Williamson, O.E. (1985). The economic institutions of capitalism. The Free Press, New York.

Zhu, S. (2006). The characteristics of ultimate shareholders and the informativeness of accounting earnings. China Accounting and Finance Review, 8(1): 25-49.

Zhu, Y. (2009). On the pyramidal structure in China. The HKU Scholars Hub, Hong Kong. 


\section{NOTES}

